\title{
Constructing Scarcity and Sensationalising Water Politics: 170 Days That Shook Athens
}

\author{
Maria Kaika \\ School of Geography and the Environment, Oxford University, Oxford, UK; \\ maria.kaika@geog.ox.ac.uk
}

\begin{abstract}
This paper examines the drought that hit Athens between 1989 and 1991 and analyses the role of this natural phenomenon as the "ferment" for ongoing political-economic transformations in the direction of liberalisation and privatisation of water management and allocation in Greece. The paper analyses how the drought was marshalled as an effective discursive vehicle to facilitate and expedite the state-led neoliberal political-economic agenda. It shows how the social consensus around a number of "emergency measures" that the state adopted to deal with a "natural" crisis was grounded in a particular discourse on water and in the political-economic "positioning" of "nature" as a source of crisis. In turn, this change in the "discursive" production of nature fused with the rhetoric and practice of market-led development and privatisation and, ultimately, facilitated important transformations in the social and political-economic (material) production of nature.
\end{abstract}

\section{Introduction: The Role of Water in Greece's Promethean Project}

Based on a case study of Athens, this paper engages with the growing body of literature on urban political ecology (Davis 1995; Gandy 1997; Huston 1997; Keil 1995; Keil and Desfor 1996; Swyngedouw 1997) and aims to contribute a detailed empirical analysis to the understanding of the political, economic, social and cultural power relations involved in supplying modern metropolises with water. ${ }^{1}$ After providing a brief outline of the history of supplying modern Athens with water, the paper will discuss the social political and economic events leading up to the 1989-1991 water-scarcity crisis. By focusing on this particular period, the paper will demonstrate how casting nature in the role of a source of crisis facilitated specific political and economic decisions concerning both nature and the city. The exposure of the political-economic character of discourses and debates over water scarcity scrutinises the dominant managerial approach towards resolving resource-scarcity problems and the tendency to translate the inevitability of natural phenomena (eg drought) into a self-explanatory inevitability of socially constructed phenomena (eg water scarcity) with very serious social, political and economic consequences. By 
revealing the ideological role of discourses over water scarcity and addressing its social construction, this paper argues against the dominant political rhetoric about the "neutral" character of the economic analysis of resources. It proves that economics is politics (Lefebvre 1968), particularly with regard to decisions about assigning exchange value to natural resources.

Athens shares her claim to a rich and complex history of water supply with most other modern metropolises, a history woven together with political, social and economic power relations (Kaika 1999). It starts from the moment the city became the capital of the modern Greek state in 1834 after the end of the Greek War of Independence against the Ottoman Empire (Clogg 1984). For almost a century (1834-1926), most efforts to water the city were channelled towards the excavation and reconstruction of the Roman Hadrian's Aqueduct, which, it was believed, would reconnect the city to its ancient veins. Despite major investment and successive projects, however, these efforts were not successful (see Gerontas and Skouzes 1963; Kalantzopoulos 1964; Koumparelis 1989). Nature's water remained awesome and undisciplined, and Athens entered the 20th century faced with severe water shortages and an ever-growing population.

However, the 20th century, along with inflows of foreign capital and an expanding Greek economy (Agriantoni 1986; Kafkalas 1981; Leontidou 1990), introduced a new role for water in Greece's modernising project: mastering and taming water was marshalled by the country's modernising elites (political, economic and cultural) as a key means through which "development" could be achieved. Large-scale infrastructure projects would provide the means to modernise the country and to "connect" modern Athens to "the West". In 1925, the first big (American) investment in water supply in Greece took place with the construction of the Marathon Dam and Reservoir, the most important engineering work to be realised in the Balkans at the time (see Gerontas and Skouzes 1963). This project became a landmark for a new era in Greek political, economic and social reality and heralded a new relationship with nature's water. Rather than being seen as "fearful and threatening", water became "the prerequisite for the country's development" and a growth engine for the country (Harvey 1996; Smith 1984).

Along with the shift in water's role came the introduction of new institutions for water management and allocation. In 1925, with the completion of the Marathon Dam, the responsibility for supplying Athens with water was transferred from the municipality to the newly founded Hellenic Water Company (EEY) operating under the jurisdiction of the state. The aqueduct, the reservoir and the distribution network, which had previously belonged to the municipality, were handed over to EEY (Ulen and Co 1930). The Marathon Dam project 
signalled the beginning of what would become a hegemonic model for the design and implementation of future water-supply projects, the biggest ones being the Lake Yliki Aqueduct (1958) and the Mornos Dam and Aqueduct (1969-1972) (Figure 1).

By the early seventies, the water shortages that previously threatened urban life had totally receded, both in reality and in people's consciousness. Greece's pursuit of her modern Promethean project for taming nature (Foster 1997) finally succeeded in bringing water into Athens after a century of water shortages. Athens' per capita consumption of water has been increasing steadily since 1926 and today is among the highest in the world (Table 1). After 1926, domestic water supply became a standard feature for every household, and a "security meter" was installed on every connection, measuring individual household consumption and introducing water as a commodity $(E Y \Delta A \Pi$ 1995). A blissful, commodified relationship became established with what was now believed to be a perfectly tamed nature.

\section{Tamed, Nationalised Water: Abundance and Optimism}

The changes in cultural and social perceptions of nature's water, including the now unproblematic and uninterrupted presence of water in people's households, contributed to experiencing the function of "the city" as independent from the function of a now tamed "nature", thus positing the city as a realm separate from nature's processes (Kaika and Swyngedouw 2000).

By the beginning of the 1980s-despite the continuous growth of its population, which had now reached 3.5 million-Athens had succeeded for the first time in its modern history in having more water than it actually needed. In 1985, the city's main reservoir, the Mornos Reservoir, literally overflowed. This was hailed as a landmark and met with public and political enthusiasm. According to I Stevis, spokesman of Athens' water supply company $(E Y \Delta A \Pi)$, by 1985 Athens held a world exclusive for permitting irrigation of agricultural land with purified water (interview, 28 July 1997). That moment signalled the ultimate success of the project of conquering nature. It was almost an act of revenge over an element that had been tormenting the city by its absence for centuries and was now finally tamed.

It was during this optimistic period that the legal and institutional basis of Greece's water resource management was totally reorganised. Law 1068/80 (1980) merged the Hellenic Water Company (EEY) and the Athens Sewerage Organisation $(O A \Pi)$ to form a unified water supply and sewerage authority, the Athens Water Supply and Sewer-

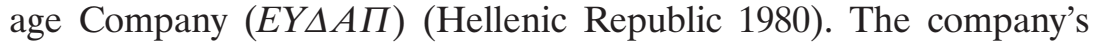
sole stockholder was the Greek state. The company operated as a public utility company, the chief objective of which-as determined by the law-was to provide all the citizens of the Metropolitan region of 


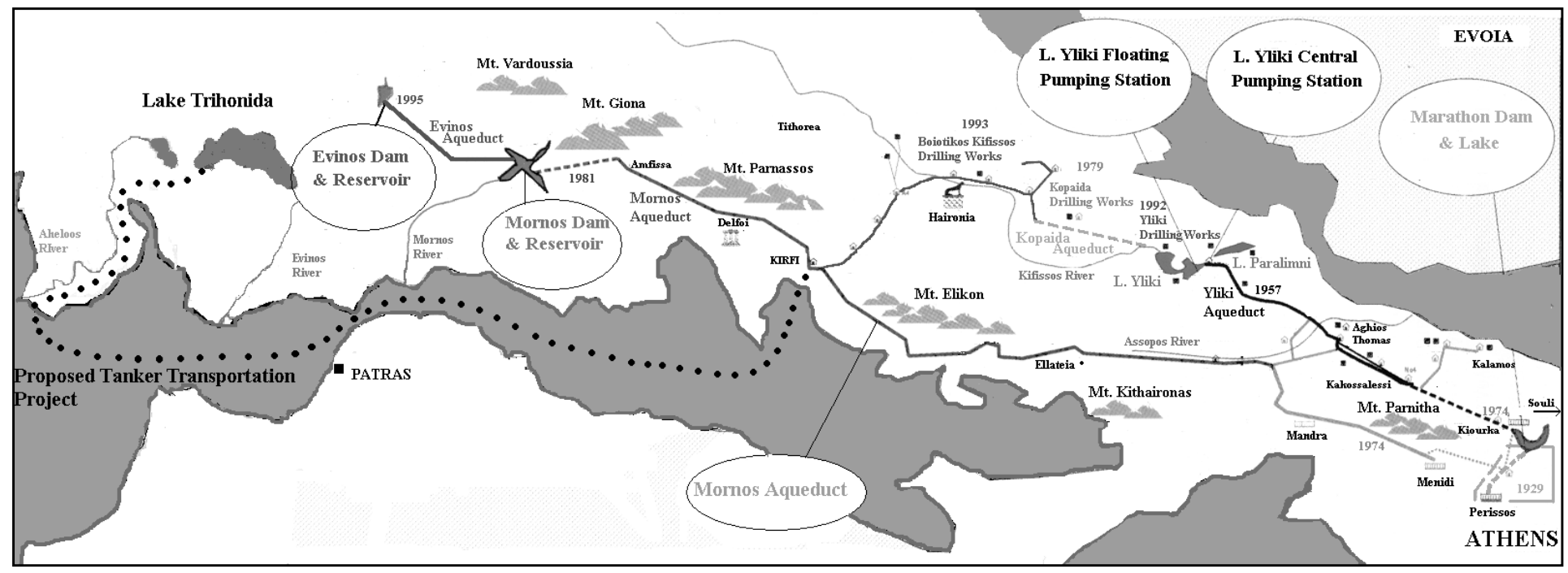

Figure 1: The water supply system for Athens. The dotted line indicates the proposed water transportation project from Lake Trihonida. Source: Compiled by the author based on background map provided by $E Y \Delta A \Pi$ and additional data from the Ministry of Environment, Planning and Public Works. 
Table 1: Water Consumption Levels Per Capita Per Day Around the World

\begin{tabular}{lclc}
\hline Country & Number of Liters & Country & Number of Liters \\
\hline Austria & 135 & Australia & 268 \\
Belgium & 122 & Canada & 326 \\
Denmark & 139 & Finland & 145 \\
France & 137 & Germany & 116 \\
Greece & 200 & Hungary & 102 \\
Ireland & 142 & Italy & 213 \\
Japan & 278 & Korea & 183 \\
Netherlands & 130 & New Zealand & 165 \\
Norway & 140 & Portugal & 119 \\
Spain & 210 & Sweden & 191 \\
Switzerland & 158 & Turkey & 195 \\
England and Wales & 150 & United States & 365 \\
\hline
\end{tabular}

Source: Environment Agency (1999:7).

Athens with potable water and sewerage services ( $E Y \Delta A \Pi 1995)$. The company's responsibility began with raw water and continued with its impoundment, transport, treatment and final distribution to the consumers in the form of potable water. The great breakthrough in planning and managing water resources, however, came in 1987, when the socialist government voted in Law 1739/87, which:

1. nationalised the management of water resources;

2. declared water a "natural gift ( $\alpha \gamma \alpha \theta \delta$ ) to be used for the satisfaction of social needs" and the right to water as "the undeniable right of every individual";

3. acknowledged domestic water supply as a priority over all other uses of water;

4. annulled all previously existing rights over water linked to private property;

5. sanctioned the right of the state to expropriate land, edifices or settlements, as well as to restrain the use of water by individuals or companies (after compensation); and

6. created a new institutional framework for the management of water resources, dividing the country into 14 hydrological departments. (Hellenic Republic 1987)

Thus, decision-making and power over water resource planning and allocation, which had been a matter of regional or local policy, was now centralised, as water resources became de facto nationalised. The general mood of optimism was also reflected in the five-year project plan (1988-1993) for Athens' water supply issued by the Ministry of Environment, Physical Planning and Public Works (YПEX $\Omega \Delta E)$ in 1988. The document confidently stated that "The Mornos reservoir 
will continue to cover the city's needs for water.... There is also scope for using the existing water supply system and available resources to also cover the needs of areas which are not yet connected to the network" (YחEX $\Omega \Delta E$ 1988:69). ${ }^{2}$ The same report proposed expanding the network to reach the new holiday resorts around Attica, the prefecture that includes Greater Athens. The plan also recommended a number of measures to improve waste disposal, expand the sewage network and improve water quality. These issues had been gaining political currency, not least because of the obligation to comply with standards set by the European Water Directives ${ }^{3}$ (Kaika 2003).

Thus, according to $Y \Pi E X \Omega \Delta E$ 's report, Athens was marching towards the 1990s with extreme confidence in the adequacy of the city's water resources-despite the continuous rise in consumption levels, which, by 1989 , reached 376 million $\mathrm{m}^{3}$ per year (Figure 2).

\section{Matching Natural with Political Crisis: From Overflowing to Scarcity}

Only one year after the publication of the 1988 report, the optimistic situation was turned on its head, as a severe drought began which was to last for almost three years (1989-1991). The drought marked the beginning of yet another new relationship with nature's water: seemingly overnight, water turned from an abundant resource, a source of optimism, into a scarce resource, a source of crisis and conflict, threatening to disrupt the functioning of the "eternal" city and its residents. During the drought period, each ministry published different numbers regarding the exact amount of raw water available, defending its own interests and strategies. For example, the estimate given by the Ministry of Agriculture was $400^{*} 10^{6} \mathrm{~m}^{3}$, that of the Ministry of Industry, Research and Technology was $221^{*} 10^{6} \mathrm{~m}^{3}$, and the water company itself gave an estimate of between $580^{*} 10^{6}$ and $630^{*} 10^{6} \mathrm{~m}^{3}(Y \Pi E X \Omega \Delta E$ 1990a; Karavitis 1998).

The sociopolitical dimensions of the initial confusion, as well as of the subsequent decisions, can only be understood when it is noted that the 1989-1991 drought coincided with one of the most turbulent periods in modern Greek politics. The country went through a deep and long political crisis when an economic and political scandal broke in which the socialist government was allegedly involved while at the height of its popular support. Within a period of less than two years, three rounds of national elections were held (see Chadjipadelis and Zafiropoulos 1994; Zafiropoulos and Chadjipadelis 2001). In the first round (June 1989) no single party achieved the necessary majority, and eventually a government was formed out of a coalition unique in modern Greek political history: between the conservatives and a communist-led left alliance. A few months later, a second round of elections (November 1989) also failed to give majority to any of the 


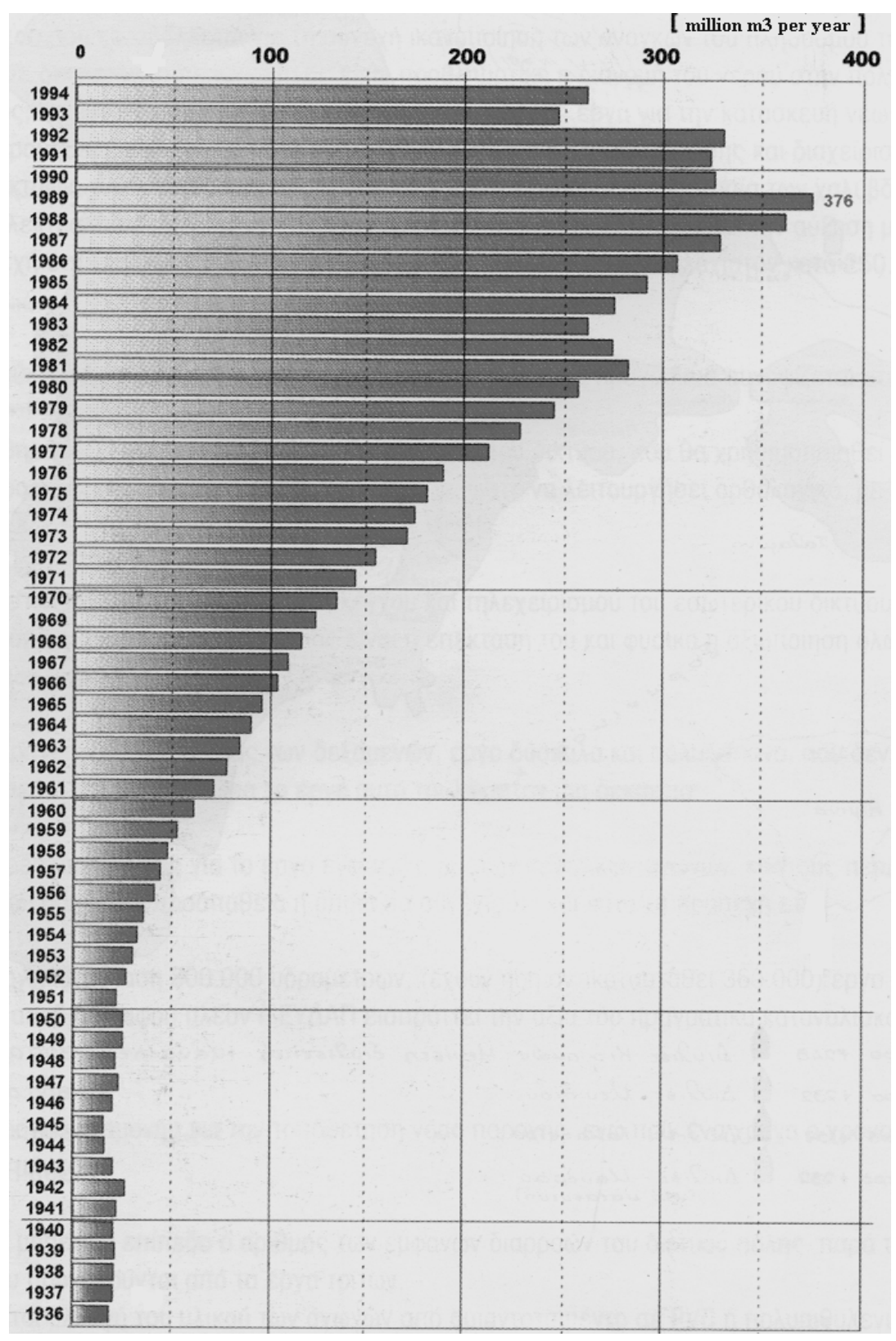

Figure 2: Increase in Athens' water consumption levels: 1936-1994. Source: EYАAП. 
main parties. This led to a second coalition between conservatives, socialists and communists (government of national unity). The third round, performed in April 1990 in the midst of pending trials of former socialist ministers, led to a Conservative party victory. This paper argues that it was precisely the fusion of a political crisis with a natural crisis, accentuated by a powerful public rhetoric casting nature as a source of crisis, that facilitated the almost uncontested implementation of a number of "Emergency Acts" of questionable soundness and transparency by the newly elected conservative government.

In fact, the crisis produced around the 1989-1991 drought was neither as unexpected nor as "nature-driven" as suggested at the time by the Greek media and by political hegemonic discourse from consecutive governments. Contrary to the optimism of the early 1980s, the water level at the Mornos Reservoir had, in fact, been falling for a number of years (Figure 3). Interviews with the administration of the water company indicated that it was sociopolitical rather than natural processes that had built up to the moment of crisis—processes including:

1. the expansion of the network and the increase in the numbers of users, without any accompanying increase in the available volume of water;

2. illegal extraction from the aquifer by individuals through local springs and wells;

3. a lack of strategic planning for water resources; and

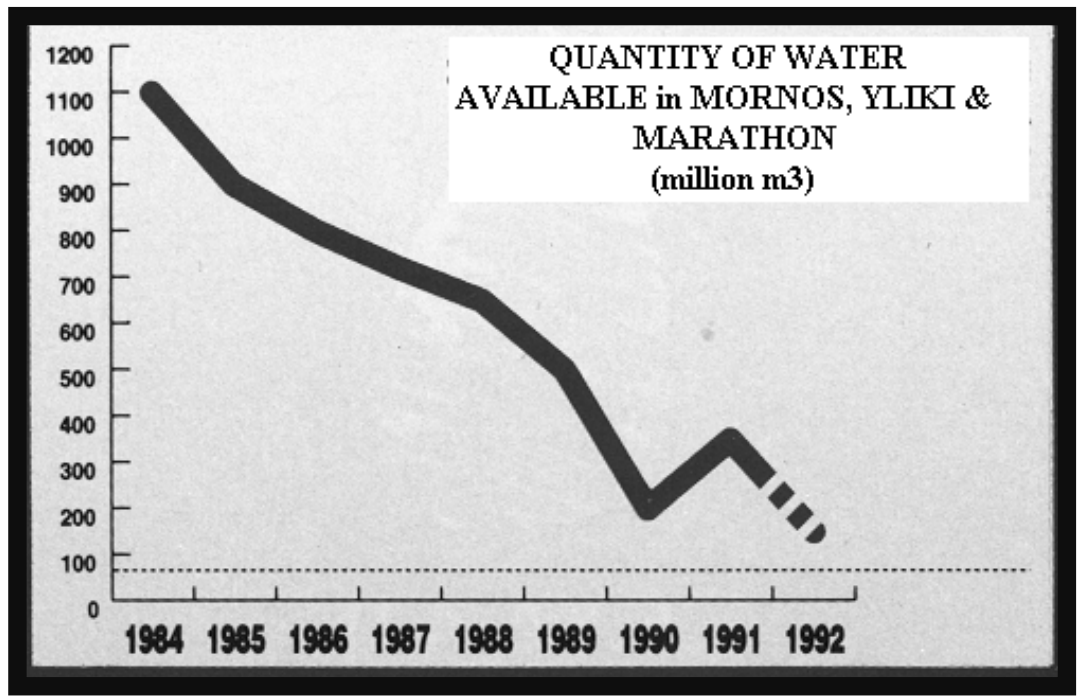

Figure 3: In 1990, the resources available in all three reservoirs reached their lowest point.

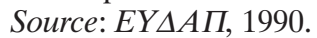


4. low prices (15 dr. [€0.04] per cubic metre in 1985), which led to unwise levels of consumption. (executive member, $E Y \Delta A \Pi$, interview, 28 July 1997)

Despite previous concerns expressed by nongovernmental bodies (NGOs) - academics, independent researchers, environmental NGOs, the Technical Chamber of Greece, and so on-that the city's future demand for water would eventually exceed the storage capacity of the reservoir (Sabbidis et al 1988), it was only in May 1990 that the crisis took on a broader, public dimension and became a key theme for sensational media coverage (see Figure 4) and heated debates in parliament and in everyday life. In what follows, I shall unravel the political, cultural, social and economic configuration that led to the political-ecological crisis, and argue that the sensationalisation of the politics of water, by casting nature into the role of a source of crisis and water as a scarce commodity, facilitated the swift implementation of a number of very controversial political decisions.

\section{Sensationalising Water Politics, Part 1: Producing Nature as Crisis}

As argued above, after a century of water shortages, cholera epidemics and political intricacies, the efforts to supply Athens with water succeeded not only in watering the city, but also in severing the intricate social, political and economic power relations behind the production and distribution of urban water. Indeed, by the 1980s, domestic water supply had become "naturalised"- that is, there was nothing more "natural" than to turn a tap and get clean water in the comfort of one's own home.

The confidence in the adequacy of water resources for Athens, the naturalisation of water supply and the reification of the social relations of its production played an important role in influencing public reaction to the 1990s crisis. The scale of public panic created when the taps-symbols of a comfortable modern life-refused to provide their services (Figure 4) was partly caused by the expectation that domestic water would always "naturally" be there. The disruption of water supply called for a comparison with the water scarcity that Athens experienced in the 19th century; indeed, histories and memoirs of the previous century's water shortages were published daily. However, although dry public fountains and long waiting hours were part of everyday experience in 19th-century Athens, they became an unfamiliar experience producing profound anxiety when experienced in the context of the 20th century - an era which had achieved the taming of nature and the overflowing of reservoirs. In short, the dry tap of the 20th century became a threat to domestic "comfort" that challenged the "naturalised" character of water supply (Kaika forthcoming). 


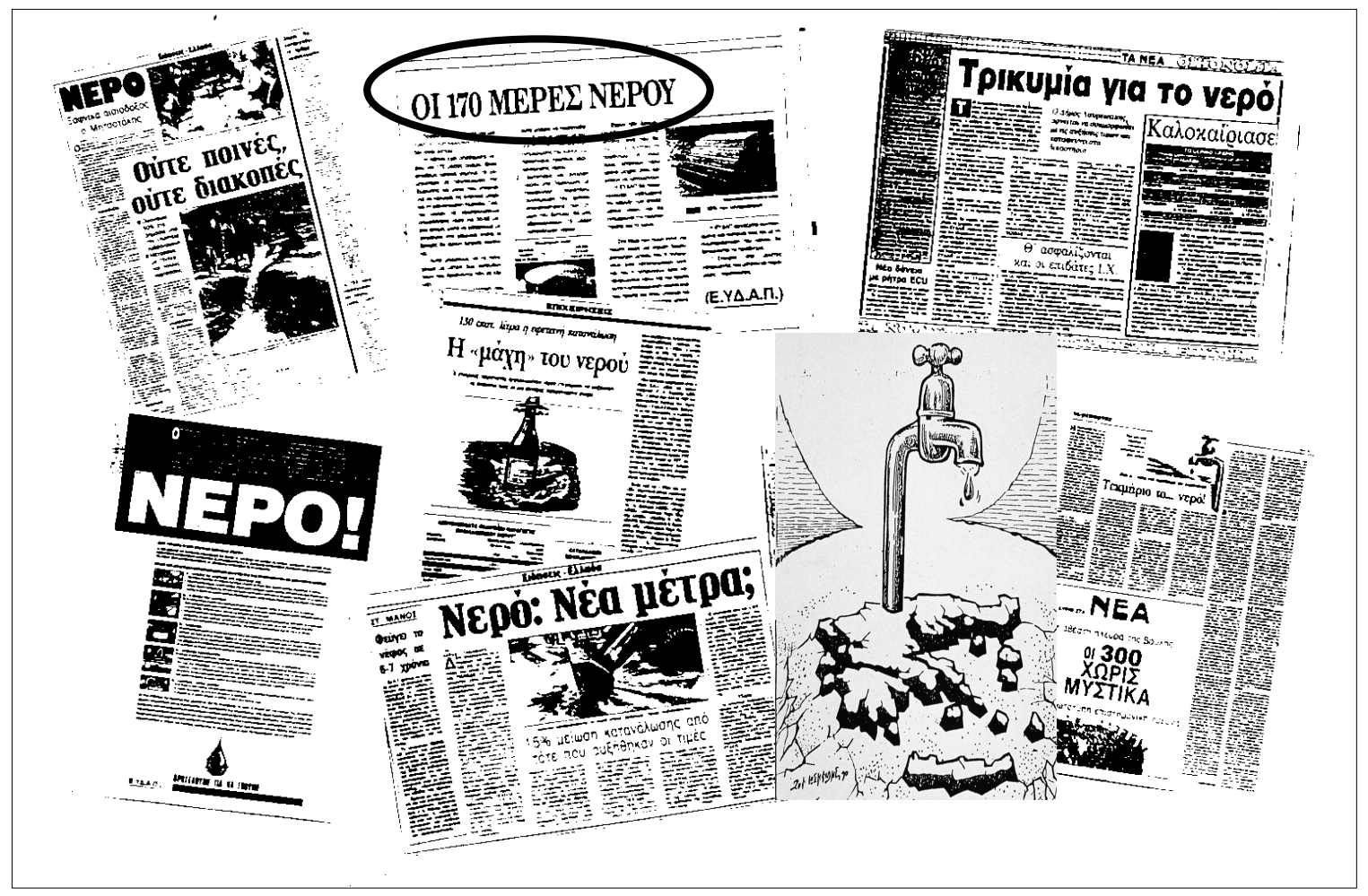

Figure 4: Author's collage of media coverage of the water-scarcity crisis. Circled is the "170 Days of Water" advertisement, which appeared daily counting the days of water (NEPO) left for Athens. 
The public anxiety and fear over the disruption of a painstakingly established sublime relationship to a "naturalised" water supply was cultivated by the media and the government and promptly used to facilitate political hegemonic practices during the 1991 crisis. Extensive media coverage and public announcements from both the state and the water company (Figure 4) insisted on casting nature in the role of a source of anxiety and crisis, threatening the orderly function of households and presenting the water crisis not as political-economic, or even political-ecological, but rather as a problem of nature. In May 1990, the water company announced that there were only 170 days of water left for Athens, an authoritative yet easily digestible statement which was taken on by the media in the form of a countdown to the day the city would die of thirst.

There were several incidents expressing the public anxiety around the well-publicised "170 days threat". One of them took the form of competition and conflict over water consumption amongst the citizens of Athens. The media's daily forecasts of the 170 days threat, combined with the reality of taps going dry inside people's homes, made Athenians turn against each other, accusing each other of "stealing" water. Instances of excessive water use, such as washing a car or watering a garden, met with verbal abuse or worse. Residents shouted at each other for "looting their water" or even called the police to report uncivil behaviour. Interestingly—but not surprisingly—such incidents had a clear class character, occurring only in the poorest neighbourhoods of Athens, in which public sensitivity to water pricing was heightened, and where very high housing densities (Vaiou, Mantouvalou and Mavridou 1995) allowed for a much closer "policing" of other people's water consumption. This was almost impossible in the secluded suburban areas, where the highest water consumers dwelt and swimming pools flourished, and where the green, dog/security-guarded estates' privacy was jealously protected.

Thus, casting nature as a source of crisis and defining water resources as scarce provided the context in which the dominant neoliberal rhetoric and attitude towards water-resource management (ie demand management through pricing) could be further applied. Indeed, as the following section illustrates, the first step towards re-establishing Athens' blissful relationship with nature was to "reassess" (ie increase) the "economic" (ie exchange) value of water. In the sections that follow, the political, social and cultural mechanisms through which this reassessment took place will be unravelled.

\section{Sensationalising Water Politics, Part 2: \\ Producing Water as a "Scarce" Commodity}

The description of water as a "scarce resource" appeared for the first time almost as an oddity in the otherwise optimistic report produced 
by $Ү \Pi Е Х \Omega \Delta E$ in 1988 , which planned confidently for the future of water supply for Athens. Strangely, and almost out of context, the same report defined water as "scarce", and presented the proclaimed surplus of water resources as a mirage:

The disparity that appears to exist between the quantity of the existing water resources and the quantity which is actually consumed by the various sectors does not correspond to a real surplus in water resources. The surplus that appears to exist ... is fictitious because:

1. the full exploitation of the country's natural surplus of water resources is not possible due to technical and economic reasons, and

2. the demand to deliver specific quantities of water in specific times and places is constantly increasing....

Given the above, one can draw the conclusion that water resources can be characterised as a "scarce" good for our country today. Their dynamic role in the production process determines the country's ability to expand its productive activities, and more often than not, determines the very productivity, profitability, and efficiency of those activities. (YПEX $\Omega \Delta E$ 1988:29-34)

In the above excerpts, the 1988 report appears to be torn between the desire to provide a populist affirmation of the country's success in eliminating water scarcity and the need to address the increasing international awareness over water resources depletion-without, however, challenging the dominant developmental logic. The report was produced only one year after the now (in)famous report of the World Commission on Environment and Development (Brundtland 1987). The Brundtland report contended that it is possible to maintain high levels of development through a more utilitarian approach towards resource management (Redclift 1994); thus, supposedly inevitably, "sustainable" development needs to be achieved by means of the market, which, the report contends, is best equipped to deal with conditions of "scarcity". In fact, the European Union's (EU) environmental policy and water legislation-with which Greece has to complyfollowed these same principles for resources management (Kaika 2003; Kallis and Butler 2001).

Within this context, the 1988 report can be seen as an initial effort to communicate the idea of market-driven water management to the Greek parliament and the Greek public by defining water as "scarce" and by singling out the market mechanism as the best means of achieving demand management. As the report asserts, the "scarcity" of water calls for a:

new, modern approach towards this natural element ... The increasing demand for water, the need to sustain the ecological balance, the unequal distribution in space and time of the country's supply and demand in water ... indicate the need for drastic intervention ... 
aiming at a more rational management of both water resources and of the projects for their exploitation.... [I]t is considered of high importance to embed the economic value of water and the need for full cost recovery into water accounting and billing policies. This is a necessary measure for protecting resources, for avoiding wasting them and for implementing a desirable water policy. (YПEX $\Omega \Delta E$ 1988: 34; emphasis added)

The text appears to be paying tribute to the "sustainability" debate emerging in Greece (see Bithas 2001; Delladetsimas 1997; Gerardi 1998; Kallis and Coccossis 2003), introducing the concept of the economic value of water as an apparently inevitable consequence of its scarce character. Although water was metered and priced before the crisis, the prices were very low and subsidised by the state, corresponding to the definition of water in Greek legislation (Law 1739/87) as a "natural gift, to be used for meeting social needs" and "an irrefutable right of every individual". However, the above report provides the first official reference to pricing as an important tool for water management, thus taking an initial and very important official step towards a radical change in Greek policy on water resources and water supply and towards the subsequent process of liberalisation and partial privatisation of the water sector.

In the next section, I shall examine how the pairing of scarcity and exchange value, coupled with the public anxiety and fear over the disruption of water services, played a central role in the political decisions taken in the form of "emergency measures" during the drought period.

\section{Nature's Crisis as a Consensus-Building Exercise: Implementing Emergency Measures}

During the 1989-1991 crisis, while everybody was paying lip service to the importance of long-term planning, the focus was actually on the production of an immediate short-term political, social and economic response to the crisis. Indeed, after a very intense but remarkably short period of political and scientific debate, the newly elected Conservative government brought four projects before Parliament in the form of "Emergency Acts" for immediate implementation (YחEX $\Omega \Delta E$ 1990a). The acts stipulated:

1. the implementation of demand-management strategies, including: a new tariff and pricing system (increasing the price of water by up to $300 \%$; a public awareness campaign; and the prohibition of heavy water-consuming activities (eg car washing, watering gardens, filling swimming pools);

2. the construction of a new dam at Evinos River, which would increase the quantity of water delivered to the Mornos Reservoir (Figure 1); 
3. the transportation of water (by means of tankers and new pipelines) from Lake Trihonida to the Mornos reservoir (Figure 1); and

4. the undertaking of drilling works along the Mornos Reservoir and the banks of Lake Yliki and the construction of a pipeline to channel water from Lake Paralimni to Lake Yliki (Figure 1).

These proposed emergency measures, having serious social, economic, political and environmental implications, were disputed by independent studies, conducted mainly by academics and environmental NGOs (Vasilakis and Bourbouras 1992; see also Table 2). However, they were voted in by the Greek Parliament under the form of "Emergency Acts", a procedure that permitted only very brief discussion in Parliament and that demanded an immediate vote. The explanation given by the government for the treatment of such important acts as emergencies was that this was absolutely necessary in order to "save the city from thirst". It was, after all, nature that was causing an indisputable crisis and from which the city needed saving.

In what follows, I shall examine the emergency measures in order to foreground the social, political, and economic implications of their swift implementation.

\section{Nature's Crisis as a Source of Exchange Value: The Alchemy and Social Stratification of Demand-Management Strategies}

The demand-management strategies that were applied in Athens as one of the Emergency Acts responding to the 1989-1991 water crisis included a public-awareness campaign, the ban on watering gardens, washing cars and filling swimming pools, and-most importantly-the decision on 8 May 1990 to enforce a retroactive increase in water prices (effective 1 March 1990). This decision increased the price paid by the consumer for a cubic meter of water by between $105 \%$ and $338 \%$ and raised water bills between $40 \%$ and $140 \%$. This happened through a

Table 2: Alternative Solutions Proposed During the Drought Period

Solution Proposed

Sealing Lake Yliki's sinkholes

Underground water from the valleys of the Boiot,

Kifissos, Kalamos and Assopos rivers

Repair of the Mornos system leakages

Recycling

Total
Estimated Yield in

Million $\mathbf{m}^{3}$

Source: data tables provided by $E Y \triangle A \Pi$. 
complex system of rates related to water consumption levels (see Table 3).

Let us look at an example of how this newly introduced system of rates worked in practice. According to statistical data provided by $E Y \Delta A \Pi$, an average household of four members consumes $15.6 \mathrm{~m}^{3}$ of water per month. Under the old rates, this household would have to pay $885 \mathrm{dr}$. (€2.59) per month for their water bill, but under the new rates the bill for the same consumption would amount to $2,187 \mathrm{dr}$. (€6.41). However, if the same family succeeded in saving $20 \%$ of its previous month's consumption, they would pay a "reduced" bill of 1,733 dr. (€5.08) per month instead (still higher than the original 885 dr.). Likewise, a family that consumed $60 \mathrm{~m}^{3}$ would originally have paid $6,140 \mathrm{dr}$. (€18.01). With the new rates, the same family would pay 22,950 dr. (€67.35). However, if the same consumer achieved lower consumption (in comparison to that of the previous month) they would get a reduction of $500 \mathrm{dr}$. (€1.46) for every $\mathrm{m}^{3}$ saved. The catch to this complex pricing system was that, as can be seen in Table 3 , higher-volume consumers were, in fact, offered a much greater price reduction for water savings than were lower-volume consumers. For example, a $30 \%$ savings in water consumption of, say, $15 \mathrm{~m}^{3}$ per month achieved by lower-volume consumers would save them around $132 \mathrm{dr}$.

Table 3: The Stratification in Water Pricing Introduced in 1990

\begin{tabular}{lc}
\hline $\begin{array}{l}\text { Consumption Level } \\
\left(\mathbf{m}^{3} \text { per month) }\right.\end{array}$ & $\begin{array}{c}\text { New Prices per } \mathbf{m}^{3} \\
\text { (drachma/euros) }\end{array}$ \\
\hline $0-5$ & $102 / 0.3$ \\
$5-20$ & $154 / 0.45$ \\
$20-27$ & $428 / 1.25$ \\
$27-35$ & $600 / 1.76$ \\
$35-$ & $750 / 2.20$ \\
\hline
\end{tabular}

Consumption Level $\left(\mathrm{m}^{3}\right.$ per month) Price Reduction for $30 \%$ Savings
in Water Consumption as \% of Total Bill
In drachma/euros per $\mathbf{m}^{3}$ Saved

\begin{tabular}{lll}
\hline 15 & $38.16 \%$ & $132 / 0.39$ \\
20 & $44.67 \%$ & $176 / 0.51$ \\
30 & $47.65 \%$ & $192 / 0.56$ \\
45 & $49.56 \%$ & $196 / 0.57$ \\
60 & $49.31 \%$ & $203 / 0.59$ \\
80 & $65.37 \%$ & $393 / 1.15$ \\
100 & $67.62 \%$ & $544 / 1.59$ \\
120 & $67.75 \%$ & $675 / 1.98$ \\
\hline
\end{tabular}

Source: Compiled by the author from data provided by $E Y \triangle A \Pi$. 
(€0.38) per $\mathrm{m}^{3}$. However, the same percentage in saving-of say, $120 \mathrm{~m}^{3}$ per month-achieved by a higher-volume consumer would save them 675 dr. (€1.98) per $\mathrm{m}^{3}$.

The alchemy introduced by the water-pricing system and watersaving incentives was highly contested by the public and by a number of organisations, including the water company itself, which had suggested only an $18 \%$ rise in water rates. The committee of the employees of $E Y \triangle A \Pi$ characterised the pricing policy implemented as "inefficient, socially unjust, profiteering and perplexing" (E0vos 1993). Nevertheless, the complex pricing system did result in an average $20 \%$ decrease in water demand.

Notably, however, the public response to the water-saving campaign and price incentives had a clear social stratification (KEПE 1996). Despite the fact that the new pricing system was designed to give greatest financial incentives to heavy users, it was, in the end, the lower-volume consumers (corresponding to lower-income households and poorer urban areas) who achieved the greatest savings and reduced their consumption by up to $30 \%$. Heavier users (corresponding to higher-income areas and houses with gardens and swimming pools) saved very little or nothing at all (Proceedings $\mathrm{O}^{\prime}$ Assembly of the Greek Parliament, 16 February 1993, Archives of the Greek State). Thus, after the increase in water prices, $18 \%$ of the domestic consumers were consuming $60 \%$ of the total water supplied, with the $3 \%$ highest-volume consumers using $40 \%$ of the total water supplied. This same $3 \%$ consumed over $60 \mathrm{~m}^{3}$ of water per month, while the average consumption for a family of four was $15.6 \mathrm{~m}^{3}$ per month (I Tsaklidis, MP, Proceedings, $\mathrm{O \Theta}^{\prime}$ Assembly of the Greek Parliament, 16 February

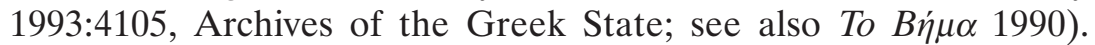
These figures indicate a clear "class" stratification, not only in water consumption, but also in sensitivity expressed as public response to a call for environmental protection and to demand-management strategies, a finding which questions the efficiency of such strategies.

Not only was the new pricing system unsuccessful in terms of the groups it was supposed to target (high-volume consumers), but it also punished lower-volume consumers by giving them no rewards for having been low-volume consumers for years and almost excluding them from price discounts, since it would be incredibly difficult for them to save further on their already low water consumption. On the basis of this injustice, one of the poorest municipalities of Athens, Lavrion, sued the government at the time, claiming that the imposed

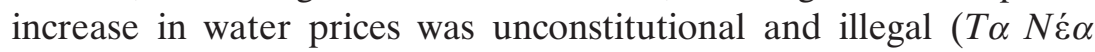
1990b). The municipality lost the case and did not get a discount for its water use. However, it was reported in Parliament by the opposition that the conservative government allegedly granted a discount of 
$70 \%$ to its own Prime Minister towards his domestic water consumption, on the basis that he was, in fact, carrying out irrigation on private agricultural land (Proceedings, $\mathrm{O \Theta}^{\prime}$ Assembly of the Greek Parliament, 16 February 1993:4114, Archives of the Greek State).

The pricing system may have failed to deliver many of its original aims. However, combined with the threat of drought-induced water scarcity and a strong political rhetoric, it facilitated the public acceptance of water as an economic resource and, finally, as a precious commodity. Still, the scarce character of water and the increase in its exchange value was attributed to the "natural" character of the resource, rather than to the actual institutional, economic and social organisation of a produced commodity. Cunningly, while the "natural/scarce" character of water resources was invoked in order to create public consensus around its increasing commodification, the very process that actually makes water a commodity-that is, its production processwas silenced. The social relations of the production and consumption of water remained in the background as if they were not part of the equation of water's availability, distribution and pricing. Ironically, even the president of the Union of Employees of the Water Company failed to address the fact that it is not nature, but the production process involved in the urbanisation of water that lies behind changes in its availability and price: "[M]arket competition cannot be applied to the case of the water company since the product this company delivers [ie water] is not produced as is, for example, electricity" (T Zaharopoulos, quoted in To Bí $\mu \alpha$ 1998b; emphasis added). Perhaps more acutely aware than anybody else of the materiality, labour-power expenditure and social relations involved in water's production, the union's president still opted to emphasise the "natural" character of water, rather than its production process, as part of his argument against the increase in water's exchange value and against the company's pending privatisation. The dominant rhetoric and the pensée unique about market liberalisation, which depicts anything produced as necessarily and automatically commodified, made the union's president resort to using "nature" as a lever for making an argument supporting the sacred human right to water: "Water is a natural good; moreover, it is scarce; therefore, it cannot be privatised" (T Zaharopoulos, quoted in To Bím 1 1998b).

It becomes clear from the above analysis that the discursive construction of water as purely natural—and thus scarce—strips the social and political meaning from water resource management and allocation. Once taken out of the social and political nexus in which they are positioned, the production, consumption and conservation of nature can be used to support almost any argument for or against privatisation; for or against the commodification of water. 


\section{Nature's Crisis as Both a Stick and a Carrot: Damming the Evinos River}

In addition to the rise in water prices, the construction of a dam at the Evinos River was also one of the emergency measures responding to the drought crisis. The Evinos River is situated in the Aetoloakarnania region, $250 \mathrm{~km}$ away from Athens (Figure 1). The proposal included the construction of a dam, $100 \mathrm{~m}$ in height with a capacity of 130 million $\mathrm{m}^{3}$, as well as the construction of a $30-\mathrm{km}$-long channel to transport the water to the existing reservoir of Mornos. From there, the water would be connected to the existing network that feeds Athens. The estimated average annual yield of water from the project would be 200 million $\mathrm{m}^{3}$, and the project was estimated to cover the city's water needs until the year 2020. The operation of the Evinos-Mornos tunnel (completed in 1995) was estimated to supplement the Mornos Reservoir with 50-120 million $\mathrm{m}^{3}$ of water per year (YПEX $\Omega \Delta E 1990 \mathrm{~b}$ ). The cost of the project was initially estimated at 55 billion dr. (€160.8 million), and $85 \%$ of the total investment cost was funded through the EU's Cohesion Fund.

The project embodied the continuation of modern Fordist development schemes and the associated large-scale transformation of nature's water, a process that started in earnest with the Marathon Dam in 1925 and became an important part of postwar urban planning and development in Greece (Emmanouil 1985; Getimis 1994; Kaika 1999; Panayiotatou 1990). However, the contemporary rise in environmental awareness means that dam constructions are no longer greeted with the same enthusiasm and consensus as in the early 20th century (Roy 1999; Topping 1995). The shrines of modern technology are no longer objects of worship and social consensus, so their construction has to be forged through means other than mere references to "progress".

In what follows, I shall examine the mechanisms through which consensus was built for the Evinos River Dam project. I shall argue that the threat of dry taps and further increases in water prices (falling under the category of the "stick"), coupled with continuous development and economic growth promised by the new dam project (falling into the category of the "carrot") worked as a very effective consensus-building mechanism.

\section{The Stick: Scarcity and Crisis}

Once again, the main justification behind the speedy implementation of the Evinos Dam project was the urgent need to address the drought. Indeed, the report published by $Ү \Pi Е X \Omega \Delta E$ on the implementation of the project stated that "One of the main planning parameters for the project will be the minimisation of construction time" (YחEX $\Omega \Delta E$ 1990b:23). 
The Evinos Dam project proposal was not entirely new. It had been suggested originally as a possible future addition to the plans for Mornos, Athens' most recent (1969-1981) dam project (see Figure 1). Since then, it had been awaiting the right conditions to be pushed through (Kingdon 1984; Nevarez 1996). Indeed, in 1991, the right configurations prevailed: economic (funding available from the EU Cohesion Fund); socioenvironmental (drought presented as water scarcity); and sociopolitical (consensus due to crisis and rising water prices combined with a turbulent political period). The above sociopolitical configuration permitted the relatively uncontested and rapid implementation of the project (Perelman 1979; Rutte, Wilke, and Messick 1987), which was unearthed from the archives to save the city from thirst. Although preliminary studies for alternative solutions were submitted to the government by environmental NGOs, academics and private engineering companies (see Table 2), they never received serious attention (Proceedings, IB' Assembly of the Greek Parliament, 11 May 1990, Archives of the Greek State). The time it would have taken to assess, evaluate and implement the alternative projects proposed (Koutsogiannis, Xanthopoulos, and Aftias 1990) was judged by the Conservative government to be too long given the supposed urgency imposed by the drought (Kallergis and Moraiti 1991). Indeed, an interviewee from the higher ranks of the Ministry of Development established a clear link between the political character of large-scale infrastructure projects and the swift character of the implementation of such projects: "One problem when carrying out studies on water resource management during a drought period is the high cost and the time-consuming character of the studies themselves, due mainly to lack of primary data. Therefore, decisions for big scale projects, which are clearly political, are normally favoured as the quickest and "cheapest' (in the short term) solutions" (Interview, Ministry of Development, Division of Management of Water Resources, 11 September 1996). Thus, once again, a crisis posed by "natural" causes was the main justification for the implementation of the Evinos project.

\section{The Carrot: Scarcity and Promises of Development}

An element as important for building public consensus for the dam project as the anxiety produced around a "natural" crisis was the promise of development brought about by major capital investment in the construction industry and the local economy. Since the end of World War II, state support for the construction industry in Greece has been an efficient and popular way of producing short-term economic growth, mainly because of the economies of scale produced by this industry and the relatively large number of people involved (Filippidis 1990; Giannakourou 2000; Kafkalas 1985; Mantouvalou and Martha 1982; Vaiou, Mantouvalou and Mavridou 2000). The industry has 
maintained its pivotal position in recent years. As K Koutlas, vice president and management director of the PROODEYTIKI construction company (contractors of the Thisavros dam for the Electricity Company of Greece), put it:

The Greek construction industry has taken on a strategic role in the economic development of our country, since it is the sector which provides the link between the inflow and the diffusion of European funds in the Greek economy.... The implementation of big infrastructure projects is linked to high-value cash flows into the Greek productive activities, which reinvigorate a series of activities in a broad range of economic sectors.... In order for the above efforts to continue to take place, it is necessary to sustain the regular flow of European funds from the 2nd and the pending 3rd European Support Framework.... These projects provide jobs for thousands of Greeks and their completion will permit further development of the country's resources ... and in general the promotion of the image of our country.... The benefits will be reaped by the country as a whole. (TEXNIKA 1997:23)

The Evinos project belongs precisely to the category of projects to which Koutlas refers in his interview-projects that will sustain economic growth, provide jobs and keep the economy ticking. Thus, despite the anticipated negative impact of the project on agriculture, cattle-grazing and natural habitats in the areas through which the river naturally flows, the proposed damming works did not raise as much opposition as one might have anticipated. Despite the existence of a strong Greek civil society, a militant agricultural sector and a recent history rich in farmers' protests, the opposition to this particular project was left almost exclusively to ecological organisations (Modinos 1990; interview, 27 July 1997). Although the political promise to keep the river's flow uninterrupted helped to create consensus among the local people, it was a more important political promise that accounted for the lack of strong civil opposition: the promise to provide employment for thousands of local people at highly attractive wages $(700,000$ dr. $(€ 2,054)$ per month, at a time when the minimum wages in Greece

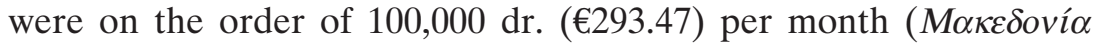
1993). For a region the people of which struggle to survive on low incomes (mainly from agriculture) and are often structurally dependent on subsidies provided by the government or the EU, the promise of development coupled with guaranteed employment for at least five years at high wages was a very significant factor in fostering social consent (Baker, Milton and Yearly 1994).

The mechanism of consensus-building is also exemplified in the interview given by the president of St Demetrios, one of the communities located in the Evinos River valley. The president produces a 
long list of problems that the Evinos project would cause for the local people and the local environment: the expropriation of land with low -and, often, delayed-financial compensation; the loss of water for the area; the continuous dynamite explosions and dust local communities would have to endure for several years; and the negative impact of the dam on the area's flora and fauna. Yet he concludes by saying: "We [the local community] would be happy to consent to the implementation of the project, provided that we, as well, got something out

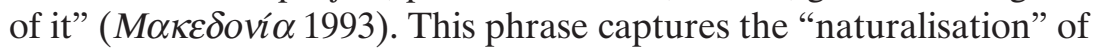
the clientelist character of political and economic relations involved in the process of implementation of big infrastructure projects. It also indicates how the promise of development becomes part of a consensusgenerating mechanism.

In fact, this way of thinking and acting permeates all levels of social and political hierarchy. For example, the response given by A Karamanlis, the then-Minister of Environment, Planning and Public Works, when questioned later in Parliament about the estimated environmental and social impact of the dam project, demonstrates a similar position:

I don't think that the water taken from Aetoloakarnania [the valley area of the Evinos River] is really depriving the area of this resource. In any case, the projects that are implemented there, as well as the ones that will be implemented in the area in the future, profit not only half of the population of Greece who live in Athens, but also the inhabitants of that particular area themselves.... We are not taking water at the expense of anyone. We make use of this water according to the letter of the law, in order to provide domestic water supply. It is our duty to do so, dear colleagues ... [S]hould we have said instead to the Athenians (to all four million of them) "No, we shall not bring water from elsewhere; go away from Athens?" Is this what you would have wanted us to say? (Proceedings, $\mathrm{P} \Lambda \Gamma^{\prime}$ Assembly of the Greek Parliament, 21 May 1993:7035-7036, Archives of the Greek State)

According to the minister's speech, the inhabitants of Aetoloakarnania had no better choice than to consent to a project that would generate economic growth in their area. Of course, this kind of growth would be as short-lived as the construction period of the dam itself-the jobs and the "positive effects" would disappear as soon as the dam was completed. Again, however, the promise was made that the shortlived effects of this kind of development would be complemented by further funding (national or EU) that would ensure a continuous flow of projects and continuous local and national development. Similarly, when the mayor of Elatteia, a village in the area of the Evinos River valley, protested in a letter to the minister of environment that the fields of the area had turned dry due to the deviation of the area's 
water towards Athens, the government replied that the matter would be dealt with in due course, through further funding from the Second

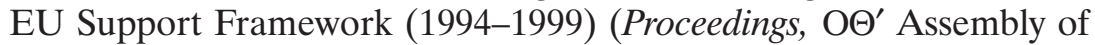
the Greek Parliament, 16 February 1993:4112 Archives of the Greek State). According to this logic, the solution to problems caused by progress resided in promises of more progress. As a management consultant to one of the biggest private construction companies in Greece $(A T T I-K A T)$ put it: "The Greek choice for development is based on immediate and short-term efforts to implement the European Support Framework, by utilising the funds provided.... [T] he Greek construction industry is on the alert to respond to the implementation of the funded works with a high sense of responsibility" (TEXNIKA 1997:22).

In an era of increasing environmental awareness, Greece subscribed to a politics and practice of "ecological modernisation", paying lip service to environmental protection while remaining loyal to a practice of development through big infrastructure projects. Hence, the crisis generated by the drought soon became constructed as a challenge to overcome through the implementation of new projects, generating the oxymoron of positing nature both as a potential source of crisis and the prerequisite for development. Within such a framework, the apparent contradiction between development and the environment can always be resolved through the right management and the application of remedial technology - that is, end-of-pipe solutions-or, in the case of drought, reaching out even further in search of new "mineable" water (Blowers 1997). However, such an approach demands considerable state intervention, which, in this case, was ensured by the implementation of Law 1739/87, which nationalised water resources and their management (YBET 1988). In this way, the solution to environmental problems moved, in effect, into the domain of expert discourse within the state apparatus (Hajer 1995), and the crisis that arose from the threat of water "scarcity" worked as a hegemonic tool to justify policies towards further development (Swyngedouw 1995).

\section{Nature's Crisis as a Source of Direct Profit: The Water-Transportation Project}

The 1991 crisis and the resulting increase in the exchange value of water offered many an opportunity for accumulation, if not profiteering. Profiteering from water supply is a phenomenon that accompanies the history of water supply of many places around the world (Swyngedouw 1997), and Athens is no exception. In the 19th century, a great number of water gurus and experts wished to sell information to the municipality about as-yet-unknown underground currents and wells, while "water vendors" were selling water of dubious quality by the glass to the thirsty Athenians. In 1990s Athens, however, profiteering 
opportunities arose in a very different social and political configuration. With nationalised water resources, water-related private enterprises could only be established and thrive with strong state support and approval.

One such enterprise was the project for water transportation from Lake Trihonida (Figure 1), which was also proposed as an emergency project/response to the drought. This proposal wound up being one of the most characteristic water-supply-related scandals of the 20th century in Greece. The idea was that, with state permission, public water could be freely appropriated from Lake Trihonida by private companies, who would then have the right to sell it back to the (public) water company in bulk at a price per cubic meter set at double the price the consumer paid for it. The water transported this way from the lake would eventually end up in the city's main reservoir, Mornos. Since the operating law on water resources (Law 1739/87) made the appropriation of water from lakes and rivers by private companies or individuals illegal, the Conservative government promptly prepared a bill to modify the law. When the bill was discussed in Parliament, the opposition (socialist party) members of Parliament (MPs) walked out of the assembly, labelling the bill as "outrageous" and leaving the conservative government to vote alone (Proceedings, $\mathrm{P} \Lambda \Gamma^{\prime}$ Assembly of the Greek Parliament, 21 May 1993, Archives of the Greek State). The Emergency Bill was approved in the record time of 16 minutes by the remaining members of Parliament. The Amending Act ordered the continuous (for a period of three to five years) and unconditional (ie independent of the city's actual needs for additional water) transportation of water to the Mornos Reservoir by means of tankers and new pipelines (Hellenic Republic 1993). The quantity of water to be transferred was set at $600,000 \mathrm{~m}^{3} /$ day from Lake Trihonida and the Anavalos River and 150,000-200,000 m³/day from the Aheloos River and Lake Paralimni (Figure 1) (Proceedings, $\mathrm{P} \Lambda \Gamma^{\prime}$ Assembly of the Greek Parliament, 21 May 1993:7035-7036, Archives of the Greek State). If the project went ahead, it would impose a significant financial burden on the already indebted public water company, but the Amending Act stated that this extra cost would be covered through state subsidies and that, therefore, the government's attempt to "sanitise" the water company's financial structure would not be jeopardised. Of course, the great loser would be the citizen, since (s)he would subsidise the new prices and projects either way.

The emergency character of the act and of the project, the legal requirement that the act stipulated to continuously transfer water for an uninterrupted period of three to five years regardless of anticipated future improvements in water supply, and a further modification of the act that set very favourable conditions for the contractor if they failed to honour the terms of the contract all suggest strong political 
and economic interests behind the implementation of the project. Moreover, it so happened that the president of the consortium $A K T \Omega P$ A.E.-BOPEIOE $\Lambda \Lambda A \triangle I K H A$ A.E., which was contracted to carry out the project, was the editor of ' $E \theta \mathrm{vo}$, a government-friendly newspaper. The contract terms were actually not published (Proceedings, $\mathrm{P} \Lambda \Gamma^{\prime}$ Assembly of the Greek Parliament, 21 May 1993:7035-7036, Archives of the Greek State). The contracts signed with private companies for the implementation of the project were characterised by the spokesman of the socialist party, P Sgouridis, as "colonial", pointing at the

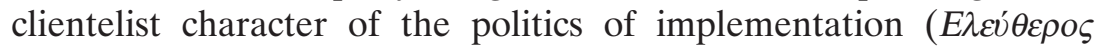
Tónos 1993).

Thus, apart from the questionable decision-making procedures, the very necessity and efficiency of the proposed scheme were also debatable, producing a political scandal on a grand scale. In their assessment of the project, the Technical Chamber of Greece (a very powerful political body) and the water company itself stated that, to start with, the planned period of ten months allowed for the construction and installation of the pipelines for the transportation of

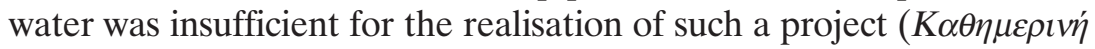
1993a). Secondly, even if everything went according to proposed timing, the transportation of water would commence in June 1994 at the earliest; only six months before the scheduled full operation of the Evinos dam project (January 1995), a project which was in any case expected to solve the water problem of Athens "for ever". This left only a very short period of six months or less during which the transportation of water to the Mornos reservoir would be of use (if at all) for alleviating Athens' water problems, assuming, of course, that the drought period would continue until then. However, the Amendment Act ordered the continuous supply of water for a much longer period of 3-5 years (1993-1996/98), irrespective of any changes in environmental conditions (drought) or in the structure of water demand or supply, thus ensuring a guaranteed income for the contractors independent of the availability of water resources. In sum, if the contracts were to be honoured, it would mean that for a period of two to four years, large quantities of probably unneeded water would be transported to Mornos at a very high public cost. Each cubic meter flowing into the Mornos reservoir in this way would cost over $200 \mathrm{dr}$. (€0.58) to the public water company, at a time when the average price for the consumer was $102 \mathrm{dr}$. (€0.29) per $\mathrm{m}^{3}$. This corresponded to over 65 billion dr. (€190.6 million) paid by the Greek public over a two year period for an, in all likelihood, unneeded daily supply of 450,000 cubic metres of water. The cost was expected to be covered partly by the consumers through further water price hikes.

The Trihonida project received fierce opposition from agricultural co-operatives and local authorities, since it constituted an activity 
whose economic benefits, unlike those of the Evinos project, would not be distributed to a broader population but instead would be reaped exclusively by a small number of individual actors and private companies. The public reaction to the project mainly took the form of fierce localism. The people of Boiotia, as well as the Agricultural Cooperative of Kopaida (where Lake Paralimni is situated), threatened to bomb the water transportation pipes. Their motto was: "Athenians, return to your villages, and there you can drink as much water as you wish"

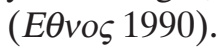

In the end, the municipality took $E Y \Delta A \Pi$ to court, and the court ordered the water company to stop pumping water from the lake. The outcome of the public competition that had been carried out by the Conservative party for the implementation of the water transportation project was questioned in Parliament and in public, as was the legitimacy of authorising private companies to appropriate water freely from rivers or lakes and subsequently sell it to the public water company (Proceedings, $\mathrm{O}^{\prime}$ 'Assembly of the Greek Parliament, 16 February 1993:4112 Archives of the Greek State). A Socialist party MP asked in Parliament:

1. whether the economic and practical feasibility of this option had been adequately researched,

2. who were the private companies that would undertake the project, and,

3. the reasons why there had not been an environmental impact assessment carried out for the project. (Proceedings, $\mathrm{P} \Lambda \Gamma^{\prime}$ Assembly of the Greek Parliament, 21 May 1993:7035-7036, Archives of the Greek State)

The reply from the Minister of Planning and Environment was stunning:

It doesn't matter who these companies are. It is not my concern. I have no reason to tell you who these companies are. It was a public competition and you can find out... [W] hen one announces a public competition and does not know who the supplier is going to be, one cannot carry out an environmental impact assessment in advance. This will happen in the future. (Proceedings, $\mathrm{P} \Lambda \Gamma^{\prime}$ Assembly of the Greek Parliament, 21 May 1993:7035-7036, Archives of the Greek State)

However, it was not the public outcry against the contested Amendment Act and the Trihonida project that prevented it from materialising, but rather the fact that the Conservative party lost its majority to the Socialist party a few months after the proposal, in the 1993 elections. After the socialists came to power, the contract for water transportation fell through when the new government refused to act as guarantor for the appointed contractor's request for a loan from 
foreign banks. Subsequently, $E Y \Delta A \Pi$ stated that it could no longer cooperate with the contractor, and thus the public tender for the project

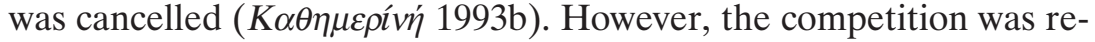
advertised in 1994. This time, all of the participating companies tendered far lower prices, ranging from 101 to $353.7 \mathrm{dr}$. ( $€ 0.29$ to $€ 1.03)$ for each $\mathrm{m}^{3}$ transported, while all the 1991 tenders exceeded

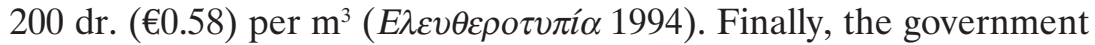
dropped the project altogether and cancelled all emergency measures regarding water consumption apart from the higher water rates. Nature's "crisis" seemed to be over, but the higher water rates were maintained as part of the process of the partial privatisation of the water company, which went ahead as part of Greece's commitment to a "third way" towards socialism.

\section{Paving the Road to Privatisation}

Of the four Emergency Bills voted on in 1990, only the one concerning the increase in water prices had a short-term impact, resulting in a $20 \%$ cut in water consumption. The immediate results of the other three emergency measures were negligible: only half of the proposed drilling works were eventually carried out, as these were highly contested by local residents; the transportation project led to great political controversy and to a political scandal before it was finally abandoned; and the Evinos Dam project only became fully operational in 2001, long after the drought period was over. Hence, the only immediate positive outcome from the proposed projects was a $20 \%$ saving in water consumption and an extra yield of a meagre $100,000-200,000 \mathrm{~m}^{3}$ per day from the drilling works. These quantities fell far short of meeting the originally estimated extra need of almost $1,000,000 \mathrm{~m}^{3}$ per day (see Table 4), suggesting a discursive, rather than material, water scarcity during the drought period. Adding to this point is the fact that

Table 4: Estimated Available Water Resources in and Estimated Water Needs for Attica in 1990, and Projected Water Needs for Attica for 2001

\begin{tabular}{|c|c|c|c|c|}
\hline $\begin{array}{l}\text { Estimated Available } \\
\text { Water Resources, } \\
1990 \text { (in million } \text { m }^{3} \text { ) }\end{array}$ & & $\begin{array}{l}\text { Estimated Water Needs } \\
\left.1990 \text { (in million } \text { m }^{3}\right)\end{array}$ & & $\begin{array}{l}\text { Projected Water } \\
\text { Needs, } 2001 \\
\left(\text { in million } \mathbf{m}^{3}\right)\end{array}$ \\
\hline From Mornos & $200-250$ & $\begin{array}{l}\text { Domestic water } \\
\text { supply }\end{array}$ & 380 & 500 \\
\hline Boiotikos Kifissos & 160 & Irrigation and & 13 & 5 \\
\hline $\begin{array}{l}\text { River } \\
\text { From Lake Yliki } \\
\text { and Lake Paralimni }\end{array}$ & 220 & $\begin{array}{l}\text { industry of Attiki } \\
\text { Irrigation of Kopaida } \\
\text { and Theba valleys }\end{array}$ & $\begin{array}{r}5 \\
160\end{array}$ & 400 \\
\hline TOTAL & $580-630$ & TOTAL & 553 & 955 \\
\hline
\end{tabular}

Source: Compiled by the author from data provided by $E Y \Delta A \Pi$. 
once the decision for the price rise was confirmed and all four Emergency Acts had been voted in, the discourse about water scarcity both in Parliament and in the media stopped abruptly, as if the mere act of adopting emergency measures had been sufficient to chase the ghost of water scarcity away. Indeed, by 19 August 1990-only three months after passing the Emergency Acts, and before any concrete results were achieved-the apocalyptic prophesies about imminent disaster had disappeared and the Minister of Environment, Planning and Public Works asserted that there would not be a water problem that year for Athens (To Bí $\mu \alpha$ 1990).

However, the adopted measures were implicated in a much wider project than providing relief for a drought period: they contributed towards asserting the economic value and the commodity character of water and towards paving the road for the privatisation of Athens' water company. The deputy prime minister's rather inelegant attempt to justify the implementation of one of the projects further supports this argument: " $[\mathrm{H}]$ aving abundant water and paying a higher rate of, for example, $500 \mathrm{dr}$. per cubic meter [the rate at the time was $102 \mathrm{dr}$. (€0.29) per $\left.\mathrm{m}^{3}\right]$, is preferable to running the risk of paying the imposed fine of 4,500 for each cubic meter of consumption over the maximum

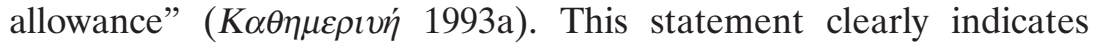
that the paramount concern was not to ensure the water supply of the average family, which was unlikely to exceed the maximum allowance anyway, but rather to meet the increasing demand of the $3 \%$ of the customers who were consuming $40 \%$ of the water in order to sustain their lifestyle (pools, gardens, etc) and who could afford to pay higher rates. In effect, the high consumption on the part of this fraction of consumers would almost always be subsidised by the state through funding further projects-and, of course, by the rest of the consumers, who would inevitably share the economic costs of these projects.

The above statement also reveals a less conspicuous agenda in Greek water politics of the early 1990s: the effort to assert the "commodity" character of water. The value that the 1987 law assigned to water as a "common good and a human right" had to be imbued with the assertion of its exchange value before the conservative government could embark on one of its main strategies-that is, the "liberalisation" (ie privatisation) of public utilities. Ironically, it would be the re-elected socialist government that would finalise the privatisation process later on, partly in response to pressures from the EU.

Apart from contributing to the reduction in water consumption, the new price schemes also contributed an extra 16 to 17 billion dr. ( $€ 47$ to $€ 50$ million) per year to $E Y \Delta A \Pi$ 's budget. This became the first step towards the public company's financial "sanitisation"- that is, the process of making an indebted public company profitable, 
usually followed by putting up the company for private bidding. In 1989, the company's total debt was 100 billion dr. (€293.5 million) and its annual deficit over 25 billion dr. (€73.3 million) (Table 5). After the implementation of the new pricing system, the company's financial situation turned around: its annual net profit amounted to 2.7 billion dr. (€7.9 million) by 1992, thus making the company attractive to investors for the first time (Board of Scientific Staff of ЕҮ ААП 1993).

It is important to note that in 1991, the conservative government did not consult the High Commission of Public Companies ( $A \Sigma K E)$ over the decision on price raises, as it was legally required to do. Moreover, the decision had not met with the unqualified approval of the water company itself, which had suggested a mere $18 \%$ rise in the cost of water price. Even the state-appointed administration of the water company did not vote in favour of the price rise. In short, the decision was made unilaterally by the State Commission for Prices and Wages. It is no wonder, then, that the new price system was seen by manyincluding the board of scientific staff of $E Y \triangle A \Pi$-as illegal. The government's justification referred, once again, to the emergency conditions associated with a nature-induced crisis: "We are faced with an urgent situation, and such a situation requires urgent measures" (Minister of Environment, Planning and Public Works, quoted in $T \alpha N \varepsilon ́ \alpha$ 1990a).

The particulars of the decision-making process were a decisive blow to the public and social character of the water company and a major step towards turning water, in the public consciousness, from a public good into a profitable commodity for sale (Proceedings, IB' Assembly of the Greek Parliament, 11 May 1990:180, Archives of the Greek State). Furthermore, as a public utility company, $E Y \Delta A \Pi$ was eligible at the time for soft loans from both the government and the EU in order to finance its deficit. For example, the company's five-year plan, effective from $1 / 1 / 1993$, to gradually replace old network pipes was financed through a 35-billion-dr. (€102.6 million) loan from the EU's Cohesion Fund. Thus, the company's pending privatisation was subsidised directly by the government and indirectly by the EU.

Table 5: Net Profit for EYАAП, 1989-1998

\section{Year}

Net Profit

(in billion drachma)

$+6$

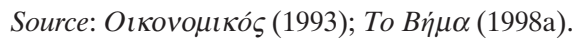


The first decisive step towards privatising the water company was taken in 1992 with the capitalisation of 130 billion dr. (€381.2 million) worth of shares in order to deal with the company's outstanding debt (Board of Scientific Staff of EY $\triangle$ АП 1993). In 1996, the government authorised a public competition for the post of the company's managing director (previously a state appointee), who was to be appointed henceforth by a consortium of private management consultancy companies. The president and members of the Administrative Council remain state appointees (To B $\dot{\eta} \mu \alpha$ 1997). The radical changes in the company's administration and financial management were presented as part of a broader project for the "modernisation" of public utility companies, sanctioned by Law 2124/96 (Interview, EY $\triangle A \Pi, 16$ November 1999).

In 1999, 49\% of the company's shares were "opened up" to private investors. This was accompanied by the implementation of the bill on the "Management and Operation of the Water and Sewerage Services Sector, and for the Regulation of the Athens' Water Supply and Sewerage Company (EY $\triangle A \Pi-A . E$.)" (Hellenic Republic 1999; see

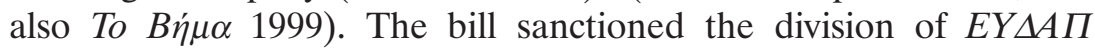
into two companies: $E Y \triangle A \Pi-A$.E., a water and sewerage company with private shareholders that would be responsible for water and sewerage services; and EПЕY $\triangle A \Pi$-Fixed Assets Company, which would remain a public company in charge of the infrastructure, land, buildings, and so on as well as being responsible for the protection and environmental management of reservoirs, lakes, and springs. The same bill sanctioned the idea that the newly founded $E Y \triangle A \Pi-A$.E. would be generously subsidised by the government during the period between 1999 and 2004 (Table 6), and ordered the establishment of a National Committee for the Regulation of the Water and Sewerage Sector to regulate $E Y \Delta A \Pi-A$.E. and other future private water and sewerage companies (Interview, ЕY $\triangle A \Pi$, 16 November 1999;

Table 6: State Subsidies Announced in 1999 for $E Y \triangle A \Pi-A$.E. for the Period 1999-2004

\begin{tabular}{lc}
\hline Year & $\begin{array}{c}\text { Amount of Subsidy } \\
\text { (in billion drachma) }\end{array}$ \\
\hline 1999 & 14 \\
2000 & 15.8 \\
2001 & 12.6 \\
2002 & 9.5 \\
2003 & 6.3 \\
2004 & 3.1 \\
\hline
\end{tabular}

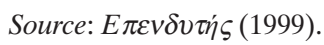




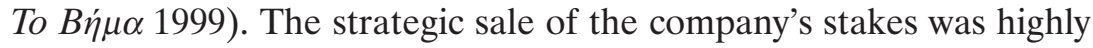
contested by the company's employees, who, during the six months that preceded the procedure, engaged in strikes and protest campaigns (To Bí $\mu \alpha$ 1998b).

\section{Conclusions: "Valuable" Nature}

The 1989-1991 drought, combined with a particular social, economic and political configuration, posited nature as the source of crisis and reintroduced the spectre of water scarcity. However, during the late 20 th century, water crisis was not the caprice of an untamed, unpredictable nature, but rather the cry of a tamed, socially produced and now vulnerable nature, which should be taken seriously in order for it to maintain its role as the prerequisite of progress and development. But the call and discourse about taking nature seriously was consummated in the assertion and re-evaluation of the exchange value of the product of the transformation of nature (ie potable water), while the social and cultural role of nature was not addressed. The resulting increase in the exchange value of water was attributed not to the fact that it is produced, but to the fact that it is natural, and thus scarce. The scheme "scarce $=$ valuable $=$ expensive" presents the increase in the exchange value of water as an inevitable, "natural" phenomenon. In this way, the inevitability of a natural phenomenon (drought) is translated into a self-explanatory inevitability of a socially constructed (Gerber 1997) phenomenon (ie water scarcity).

If, instead, we view nature not as external to society, but as socially produced (Lefebvre [1974] 1994; Smith 1984), we can move from a point of view that accounts for the identification of drought as water scarcity to a thesis - the production of nature - that points directly to the relation between nature and society and to the social production of resources. In this light, the water shortages in Athens during the early 1990s are not the direct outcome of a prolonged dry period, but rather the outcome of the interaction between the available resources, the transformation of nature by human beings and the economics, politics and culture of water use. In effect, the projects proposed in 1990 that are examined in this paper provided less of a solution to an environmental problem, and more of a means to sustain the socioenvironmental transformation called Athens. In other words, the raison d'être of the rise in water prices, of the dam construction and of the tanker transportation project was to sustain the existing socioeconomic order of things-including existing economic and cultural patterns of water use-and to allow a number of actors to profit from a crisis situation. Most importantly, it paved the way for privatisation and fed into the wider neoliberal agenda that has become hegemonic, not only in Greece but around the world, through shifting power relations between scales and actors. 
Indeed, the social construction of the water crisis became a very powerful tool for acquiring public consensus over the privatisation of yet another public utility. The split of the public water company into two companies and the introduction of a socially stratified water pricing system contributed to the enterprise of establishing what Graham and Marvin (1999:91) term a "utility patchwork with increased variations in tariffs, and styles of service provision". Such a patchwork diffuses not only public funds and efforts, but also responsibility over the distribution of resources, requiring the establishment of an entangled network of regulation, which further depletes public resources while not allowing for reinvestment of profits in public services. Therefore, it becomes increasingly important for academic work to question the pensée unique about market solutions to problems of management and distribution of natural resources, and the body of academic literature addressing these questions becomes more political than ever.

\section{Acknowledgments}

Many thanks to Erik Swyngedouw, whose valuable comments on earlier versions of the paper were very helpful. Thanks to Grigoris Kafkalas, Laila Smith and Dina Vaiou for their constructive criticism, as well as to David Dodman for his comments. Special thanks to Athens' Water Company (EY $\Delta \mathrm{A} \Pi)$, the Greek Ministry of Environment, Physical Planning and Public Works (YחEX $\Omega \Delta \mathrm{E}$ ) and the staff at the Library of the Greek Parliament and at the National Library of Greece. Financial support from the Greek State's Scholarships Foundation (IKY) made this research possible.

\section{Endnotes}

${ }^{1}$ This paper draws on original material from the Archives of the Greek State, located in the Greek Parliament Library, Athens, Greece, and the National Library of Greece in Athens, Greece. For the period between 1985 and 1995, in particular, transcripts of the Proceedings of the Assemblies of the Greek Parliament, which are located in the collection of the Archives of the Greek State, were very helpful. These archives were subsequently cross-referenced with archival material obtained through a systematic search of the National Newspapers Archive, which is part of the Greek National Library and was located, at the time of the research (1995-97), at the Old Parliament Building in Athens, Greece. These resources are currently available on the Web (see bibliography for references). The archival research was complemented by interviews with key interlocutors at the Ministry of Environment, Physical Planning and Public Works $(Y \Pi E X \Omega \Delta E)$ the Ministry of Agriculture, the Water Resources Management Division and the Water Company of Athens $(E Y \triangle A \Pi)$.

${ }^{2}$ Unless otherwise stated, all translations from Greek are the author's own.

3 The Drinking Water Directive came in effect from 1980 onwards and was reviewed with respect to quality standards in 1991.

\section{References}

Aggelakis A N and Kotselidou O N (1997) Management of water resources in Greece and the contribution of the municipal water supply and sewerage enterprises. 
In Conference Proceedings. Athens "The Policies for Water Resource Management" National Technical University of Athens (Е.М.П.), Athens, 19 November

Agriantoni C (1986) The Beginning of Industrialisation Process in Greece During the 19th Century. Athens: Commercial Bank of Greece. In Greek

Andreadis I and Kaplanidis A (1991) "Irrigation needs of the Attica basin: Problems of co-management of water resources: Possibilities for water recycling". Paper presented at Conference on The Water Problem of Athens, organised by the Greek Geological Society and the Geo-Technical Chamber of Greece, National Research Foundation, Athens, 26 April

Andrikopoulou E and Kafkalas G (1985) The Regulation of the Peripheral Space: Theory and Practice. Thessaloniki: Paratiritis. In Greek

Archives of the Greek State, Greek Parliament Library, Athens, Greece

Baker S, Milton K and Yearly S (eds) (1994) Protecting the Periphery: Environmental Policy in Peripheral Regions of the European Union. Ilford: Frank Cass

Bithas K (ed) (2001) Sustainable Cities: Theory_Politics. Athens: Typothito. In Greek Blowers A (1997) Environmental policy: Ecological modernisation or the risk society? Urban Studies 34(5-6):845-871

Board of Scientific Staff of $E Y \triangle A \Pi$ (1993) Announcement of the Board of Scientific

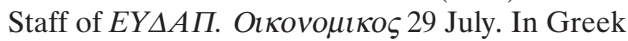

Brundtland G H (1987) Our Common Future: World Commission on Environment and Development Report. Oxford: Oxford University Press

Burgel G (1975) Athènes: Étude de la Croissance d'une Capitale Méditerranéene. Lille: Átelier Reproduction des Thèses, Université Lille III

Chadjipadelis T and Zafiropoulos C (1994) Electoral changes in Greece during 1981-1990. Political Geography 13(6):492-514

Christofilopoulos D (1989) Planning and Programming as a Process of Production of City-Plans. Athens: Sakkoula. In Greek

Clogg R (1984) A Short History of Modern Greece. Cambridge, UK: Cambridge University Press

Davis M (1995) Los Angeles after the storm: The dialectic of ordinary disaster. Antipode 27(3):221-241

Delladetsimas P M (1997) Sustainable development and spatial planning: The case of Greece. Topos 12:31-54. In Greek with English abstract

Emmanouil D (1985) Land use and housing policy in the case of urban expansion: A framework for analysis and planning for Athens. In G Kafkalas (ed) Planning: Theory, Institutions, Methodology (pp 135-191). Thessaloniki: Paratiritis. In Greek

Environment Agency (1999) Demand Management Bulletin. No 36. Environment Agency: Demand Management Centre

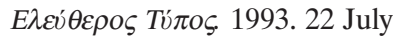

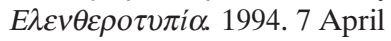

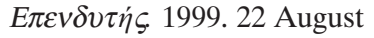

Eөvos. 1990. 22 June

Eөvo५. 1993. 10 February

ЕYААП (Water Company of Athens) (1995) Photographic Review. Athens: Water Company of Athens. In Greek and English

Filippidis D (1990) Regarding the Greek City: Postwar Trends and Future Perspectives. Athens: Themelio. In Greek

Foster J B (1997) Marx and the environment. In M Wood, E Foster and J Bellamy (eds) In Defense of History: Marxism and the Postmodern Agenda (pp 150-162). New York: Monthly Review Press

Gandy M (1997) The making of a regulatory crisis: Restructuring New York City's water supply. Transactions; Institute of British Geographers 22:338-358 
Gerardi K (1998) Strategy for a Sustainable Development of Greater Athens. Athens: Department of Planning, National Technical University of Athens. In Greek

Gerber J (1997) Beyond dualism: The social construction of "nature" and the natural and social construction of human beings. Progress in Human Geography 21(1):1-17

Gerontas D and Skouzes D (1963) The Chronicle of Watering Athens. Athens. In Greek Getimis P (ed) (1994) Urban and Regional Development: Theory, Analysis, and Politics. Athens: Themelio. In Greek

Giannakourou G (2000) The institutional framework of urban development in Greece: Historical transformations and contemporary demands. In D Oikonomou and G Petrakos (eds) The Development of Greek Cities: Interdisciplinary Approaches for Urban Analysis and Politics (pp 457-480). Volos: University of Thessaly. In Greek

Gizeli V and Chrampanis P (1985) Illegal housing. In A Dimopoulos (ed) Athens into the 20th Century, 1900-1940: Athens, the Capital of Greece (pp 143-149). Athens: Ministry of Culture. In Greek with English abstract

Graham S and Marvin S (1999) Cities, regions and privatised utilities. Progress in Planning 51(2):91-161

Hajer M A (1995) The Politics of Environmental Discourse: Ecological Modernization and the Policy Process. Oxford: Oxford University Press

Hansen A (1993). The Mass Media and Environmental Issues. Leicester: Leicester University Press

Harvey D (1996) Justice, Nature and the Geography of Difference. Oxford: Blackwell

Hellenic Republic (1980) Law 1068/80 on the Establishment of a Unified Water and Sewage company for Athens. Official Gazette of the Greek State (ФEK) 190A. Athens: National Press. In Greek

Hellenic Republic (1987) Law 1739/87 on Water Resources Management. Official Gazette of the Greek State ( $\Phi E K)$ 201A. Athens: National Press. In Greek

Hellenic Republic (1993) Law 2118/1993 on Measures Against Water Scarcity. Official Gazette of the Greek State ( $\Phi E K)$ 23A. Athens: National Press. In Greek

Hellenic Republic (1999) Law 2744/1999 on Management and Operation of the Water and Sewerage Services Sector, and for the Regulation of the Athens' Water Supply and Sewerage Company (EY $\triangle A \Pi$-A.E.). Regulation of EY $\triangle A \Pi$. Official Gazette of the Greek State ( $\Phi E K)$ 222A. Athens: National Press. In Greek

Huston S (1997) Urban political ecology: An introduction. Capitalism, Nature, Socialism 8(29):131-138

Kafkalas G (1981) Regional organisation of the Greek economy: 1948-1974. City and Region: Journal of Spatial Studies (2):7-38. In Greek with English abstract

Kafkalas G (ed) (1985) Planning: Theory, Institutions, Methodology. Thessaloniki: Paratiritis. In Greek

Kaika M (1999) "Modernity and the Urban Spaces of Produced Nature: the Politics and Culture of the Urbanisation of Water in Athens (1834-1999)." DPhil Thesis, School of Geography and the Environment, University of Oxford

Kaika M (2001) Modernity and the urban spaces of produced nature: The politics and culture of the urbanisation of water in Athens. Topos 16:151-154. In Greek with English abstract

Kaika M (2003) The Water Framework Directive: A new directive for a changing social, political and economic European framework. European Planning Studies 11(3):299-316

Kaika M (forthcoming) Interrogating the geographies of the familiar: Domesticating nature and constructing the autonomy of the modern home. International Journal of Urban and Regional Research

Kaika M and Swyngedouw E (2000) Fetishising the modern city: The phantasmagoria of urban technological networks. International Journal of Urban and Regional Research 24:120-138 
Kalantzopoulos T (1964) The History of Water Supply of Athens. Athens: Palamari Kathrogianni and Co. In Greek

Kallergis G and Moraiti E (1991) "The water problem of the Athens Basin". Paper presented at Conference on The Water Problem of Athens, organized by the Greek Geological Society and the Geo-Technical Chamber of Greece, National Research Foundation, Athens, 26 April. In Greek

Kallis G and Coccossis H (2003) Managing water for Athens: From the hydraulic to the rational growth paradigm. European Planning Studies 11(3):245-261

Kallis G and Butler D (2001) The EU water framework directive: Measures and implications Water Policy 3(2):125-142

Karavitis Ch (1998) Drought and urban water supplies: The case of metropolitan Athens. Water Policy 1:505-524

Karydis D (1990) Reading Urban Planning: the Social Meaning of Spatial Forms. Athens: National Technical University of Athens. In Greek

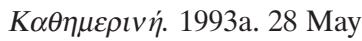

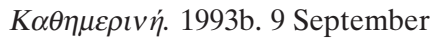

KЕПЕ (1996) The Socioeconomic Identity of the Water Departments. Athens, Ministry of Development, Centre for Planning and Economic Research. In Greek

Keil R (1995) The environmental problem in world cities. In P L Knox and P J Taylor (eds) World Cities in a World-System (pp 280-297). Cambridge, UK: Cambridge University Press

Keil R and Desfor G (1996) Making local environmental policy in Los Angeles. Cities 13(5):303-313

Kingdon J W (1984) Agendas, Alternatives and Public Policies. Boston: Little Brown

Koumparelis S G (1989) The History of the Water/Sewerage Works of the Capital. Athens: The Sewerage Company of Athens and the Water Company of Athens. In Greek

Koutsogiannis D, Xanthopoulos Th and Aftias E (1990) Exploration of Available Scenarios for Watering Greater Athens. Final Report, Issue 18. Athens: National Technical University of Athens. In Greek

Lefebvre H (1968) Le Droit à la ville. Paris: Anthropos

Lefebvre H ([1974] 1994) The Production of Space. Oxford: Blackwell

Leontidou L (1990) The Mediterranean City in Transition: Social Change and Urban Development. Cambridge, UK: Cambridge University Press

Lipietz A (1996) New tendencies in the international division of labor: Regimes of accumulation and modes of regulation. In A J Scott and M Storper (eds) Production, Work, Territory: The Geographical Anatomy of Industrial Capitalism (pp 16-40). London: Allen and Unwin

Mantouvalou M and Martha L (1982) The economic "wonder" and its traps. Anti 199:25-28

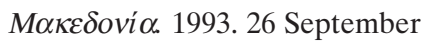

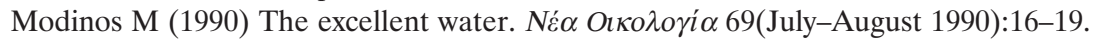
In Greek

Mylopoulos G (1997) "Managing water resources: Crisis in water management or crisis in water resources?" Paper presented at conference on The Policies for Water Resource Management, National Technical University of Athens, Athens, 19 November

National Newspapers Archive. Greek National Library. Formerly located at Old Parliament Building, Athens, Greece

Nevarez L (1996) Just wait until there's a drought: Mediating environmental crises for urban growth. Antipode 28(3):246-272

Oıкоvоцıќ́ ৎ review. 1993. 29 July

Panayiotatou E (1990) Themes in Spatial Development. Athens: Symmetria. In Greek 
Peirounakis N G (1995) Public companies and the economy. Oikonomikos Taxydromos 5(October):49-78. In Greek

Perelman M (1979) Marx, Malthus and the concept of natural resource scarcity. Antipode 11(2):80-92

Poulantzas N (1976) Current problems of Marxist research on the State. Anti 58:19-24

Redclift M (1994) Reflections on the 'sustainable development' debate. International Journal of Sustainable Development and World Ecology 1:3-21

Roy A (1999) The Cost of Living. London: Flamingo

Rutte C, Wilke H and Messick D (1987) Scarcity or abundance caused by people or the environment as determinants of behavior in the resource dilemma. Journal of Experimental Social Psychology 23(3):208-216

Sabbidis K, Ampakoumkin A, Kotzampasakis S, Kabounidis Patsoukis N and Fessas D (1988) Workgroup Report on Mornos. Athens: Technical Chamber of Greece. In Greek

Smith N (1984) Uneven Development: Nature, Capital and the Production of Space. Oxford: Blackwell

Swyngedouw E (1995) The contradictions of urban water provision. Third World Planning Review 4(17):387-405

Swyngedouw E (1997) Power, nature and the city: The conquest of water and the political ecology of urbanization in Guayaquil, Ecuador, 1880-1990. Environment and Planning $A$ 29(2):311-332

T $\alpha$ NÉ $\alpha$. 1990a. Interview, Minister of Environment, Planning and Public Works. 9 May

$T \alpha N \varepsilon ́ \alpha .1990$ b. 11 May

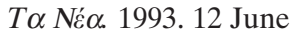

TEXNIKA. 1997. Public works in Greece. 131(October):22-23

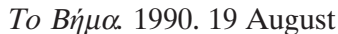

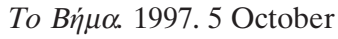

To Bí $\mu \alpha .1998$ a. 12 March

To Bं́ $\mu \alpha$. 1998b. Interview with T Zaharopoulos. 24 May

To Bí $\mu \alpha$. 1999. 22 August

Topping A R (1995) Ecological roulette-Damming the Yangtze. Foreign Affairs 74: 132-146

Ulen and Co (1930) The New Water Supply for Athens, Piraeus and Environs. Athens: Pallis

Vaiou D, Mantouvalou M and Mavridou M (1995) Social inclusion and urban development in a United Europe. To Vima ton Koinonikon Epistimon 16:29-57. In Greek

Vaiou D, Mantouvalou M and Mavridou M (2000) Postwar Greek planning between theory and chance. In A Defner, P Loukissas, M Marmaras, S Tsilenis and V Hastaoglou (eds) Conference Proceedings, "Planning in Greece 1949-1974": 2nd conference of the Greek Society for Urban History and Planning (pp 25-38). Volos, University of Thessaly. In Greek

Vasilakis K and Bourbouras D (1992) The Diversion of Evinos River for the Water Supply of Attica: Consequences, Alternatives. Athens: Greek Ornithological Society. In Greek

rBET (Ministry of Industry, Research and Technology) (1988) Law 1839/87 on Water Resource Management: Gaps, Problems and Implementation. Athens: Water Resource Directorate, $\Upsilon B E T$. In Greek

ҮПЕХ $\Omega \Delta E$ (Ministry of Environment, Physical Planning and Public Works) (1988) Report and Five-Year Plan for Water Resources Management. Athens: YBET. In Greek

ҮПЕХ $\Omega \Delta E$ (Ministry of Environment, Physical Planning and Public Works) (1990a) Study for Increasing Athens' Water Supply to Cover Needs until 2030. Part 1. Report no 8976701. Athens: YПEX $\Omega \Delta E$, Directorate $\Delta 6$. In Greek

ҮПЕХ $\triangle \Delta E$ (Ministry of Environment, Physical Planning and Public Works) (1990b) Preliminary Report for the Reinforcement of the Capacity of the Mornos Aqueduct 
System through the Evinos River Basin. Report no 8976701. Athens: Division of Public Works, YПEX $\Omega \Delta E$. In Greek

Zafiropoulos C and Chadjipadelis T (2001) The geography of elections, 1985-1993: A principal of component analysis. Topos 16:91-110. In Greek with English abstract Zeri C and Papageorgiou K (1991) The state of the Greek environment. In European Environmental Yearbook: Water Supply:48-50. Reprinted, Athens: Hellenic Society for the Protection of the Environment and the Cultural Heritage. In Greek and English

\section{Greek Newspaper Sources on the Web:}

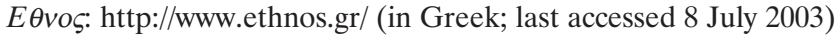

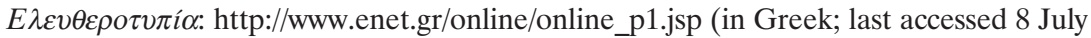
2003)

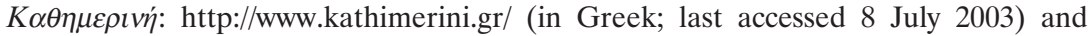
http://www.ekathimerini.com/ (in English; last accessed 8 July 2003)

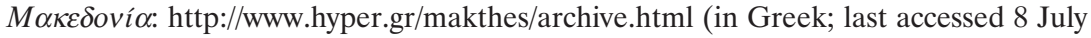
2003)

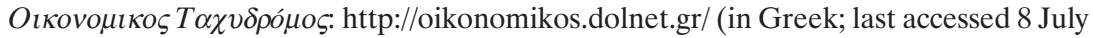
2003)

To Bí $\mu \alpha$ : http://tovima.dolnet.gr/ (in Greek; last accessed 8 July 2003)

Ta NÉ $\alpha$ : http://ta-nea.dolnet.gr/ (in Greek; last accessed 8 July 2003) 